\title{
Ethanol Electrooxidation on Pt-Sn and Pt-Sn-W Bulk Alloys
}

\author{
D. M. dos Anjos, ${ }^{a, b}$ F. Hahn, ${ }^{a}$ J. -M. Léger, ${ }^{a}$ K. B. Kokoh ${ }^{a}$ and G. Tremiliosi-Filho ${ }^{*, b}$
}

\author{
${ }^{a}$ Equipe Electrocatalyse, UMR 6503 CNRS, Université de Poitiers, 40 Avenue du Recteur Pineau, \\ 86022 Poitiers Cedex, France
}

${ }^{b}$ Instituto de Quimica de São Carlos, Universidade de São Paulo, CP 780, 13560-970 São Carlos-SP, Brazil

\begin{abstract}
A oxidação de etanol foi estudada sobre eletrodos Pt-Sn e Pt-Sn-W preparados em forno a arco elétrico. Diferentes técnicas eletroquímicas, tais como voltametria cíclica e cronoamperometria foram utilizadas para avaliar a atividade catalítica desses materiais. O processo de eletro-oxidação também foi investigado in situ por espectroscopia de reflectância na região do infravermelho para determinar intermediários adsorvidos e produtos da reação. Os resultados experimentais indicaram que as ligas Pt-Sn e Pt-Sn-W são capaz de oxidar etanol principalmente para acetaldeído e ácido acético. $\mathrm{CO}$ adsorvido também foi detectado, demonstrando a viabilidade do rompimento da ligação $\mathrm{C}-\mathrm{C}$ na molécula de etanol durante o processo de oxidação. Adicionalmente, o CO adsorvido foi oxidado a $\mathrm{CO}_{2}$. Esse produto de reação foi claramente detectado por SNIFTIRS. O catalisador Pt-Sn-W mostrou um melhor desempenho eletroquímico em relação ao Pt-Sn e este, por sua vez, é melhor do que Pt pura.
\end{abstract}

Ethanol oxidation has been studied on Pt-Sn and Pt-Sn-W electrodes prepared in an arc-melting furnace. Different electrochemical techniques like cyclic voltammetry and chronoamperometry were used to evaluate the catalytic activity of these materials. The electro-oxidation process was also investigated by in situ infrared reflectance spectroscopy in order to determine adsorbed intermediates and reaction products. Experimental results indicated that Pt-Sn and Pt-Sn-W alloys are able to oxidize ethanol mainly to acetaldehyde and acetic acid. Adsorbed $\mathrm{CO}$ was also detected, demonstrating the viability of splitting the $\mathrm{C}$ - $\mathrm{C}$ bond in the ethanol molecule during the oxidation process. The adsorbed $\mathrm{CO}$ was further oxidized to $\mathrm{CO}_{2}$. This reaction product was clearly detected by SNIFTIRS. Pt-Sn-W catalyst showed a better electrochemical performance than Pt-Sn that, in it turn, is better than Pt-alone.

Keywords: ethanol oxidation, direct ethanol fuel cell, platinum-tin, platinum-tin-tungsten, in situ Infrared Reflectance Spectroscopy

\section{Introduction}

Ethanol is a molecule of considerable interest because of its importance and potential use as renewable fuel (can be obtained from sugar cane for example) for fuel cells applications. ${ }^{1-4}$ Among the various alcohols which can be used as alternative fuel, ethanol is the most promising one because it is a safer molecule comparatively to methanol. As a liquid, it is easy to store and handle when comparing to hydrogen. Moreover, ethanol has a high theoretical energy $\left(8 \mathrm{kWh} \mathrm{kg}^{-1}\right.$ against $6.1 \mathrm{kWh} \mathrm{kg}^{-1}$ for methanol and $33 \mathrm{kWh} \mathrm{kg}^{-1}$ for pure hydrogen without

\footnotetext{
*e-mail: germano@iqsc.usp.br
}

storage). ${ }^{5,6}$ Ethanol main disadvantage comes from its molecular structure with a carbon containing a primary alcohol function and a methyl group. This characteristic induces a hard conversion of ethanol into carbon dioxide due to the difficult to break the $\mathrm{C}-\mathrm{C}$ bond and promote the complete oxidation of the methyl group with $\mathrm{Pt}$ as electrocatalyst. ${ }^{7-9}$

Several studies on the ethanol electrooxidation focused mainly to identify adsorbed intermediates showed the presence of carbon monoxide species strongly adsorbed at the electrode surface. Many studies using Differential Electrochemical Mass Spectrometry (DEMS) and in situ Fourier Transform Infrared Reflectance Spectroscopy (FTIRS) provided identification of intermediates 
and reaction products. DEMS experiments identified acetaldehyde and $\mathrm{CO}_{2}$ as primary reaction products, and using isotope labelling strategies, these studies showed that acetaldehyde is formed by cleavage of the $\mathrm{C}-\mathrm{H}$ bonds with the $\alpha$-carbon and the hydroxyl group, while $\mathrm{CO}_{2}$ is formed through a multistep pathway involving a strongly bond intermediate. These experiments also indicated that the carbon atom in the $\mathrm{CO}_{2}$ product formed is originated either from the methyl group or from alcohol group of ethanol. ${ }^{11-14}$ Elsewhere, methane and ethane were also detected as adsorption products probably issued from the methyl radicals formed during $\mathrm{C}-\mathrm{C}$ bond cleavage. ${ }^{12,13}$ Further FTIRS experiments have also shown that adsorbed carbon monoxide was an important intermediate, strongly adsorbed at the Pt surface. ${ }^{14-28}$ As pointed out above, modification in catalyst composition becomes necessary to enhance ethanol electrocatalytic oxidation and to decrease the poisoning of the catalyst by adsorbed CO. Recent studies have shown that bimetallic Pt-based catalysts can enhance the oxidation of $\mathrm{CO}$ and small organic molecules due to the bifunctional or the electronic (or ligand) effects or the combination of both. A third transition metal (M) (such as Ru, Sn, Mo, Rh, Os etc) can also be introduced as co-catalyst in the composition of the electrode material. ${ }^{29-35}$ It is well known that $\mathrm{PtSn}$ is actually the most interesting catalyst for ethanol oxidation, although some contradictory results can be found in the literature. ${ }^{32-35}$ These bimetallic materials improved the catalytic effect of platinum by a bifunctional mechanism where partially oxidized $\mathrm{M}$ at the surface supplies oxygenated species for improving the oxidation of the adsorbates. A catalytic effect can also be explained by the ligand effect where the metal $\mathrm{M}$ atoms close to Pt are expected to influence the density of electronic states of $\mathrm{Pt}$, leading to the weakening of the Pt-CO bond. ${ }^{36-39}$

The present work focuses on ethanol oxidation on $\mathrm{Pt}$ alloy catalysts (Pt-Sn and $\mathrm{Pt}-\mathrm{Sn}-\mathrm{W}$ ) prepared by an arc-melting furnace process. Chronoamperometric measurements were performed with each catalyst in order to compare their electroactivities to that of Pt alone. Results obtained from the study of the electrooxidation of ethanol by FTIRS were discussed in terms of reaction mechanism.

\section{Experimental}

Polycrystalline Pt-Sn and Pt-Sn-W alloys electrodes with 80:20 and 65:30:5 nominal composition, respectively, were prepared in an arc-melting furnace under argon atmosphere $\left(13 \times 10^{-5}\right.$ bar $)$. Pt-Sn-W and Pt-Sn basic atomic compositions was evaluated by EDX microanalyses.
The electrochemical activity of the materials was examined in $0.2 \mathrm{~mol} \mathrm{~L}^{-1} \mathrm{C}_{2} \mathrm{H}_{5} \mathrm{OH}+0.5 \mathrm{~mol} \mathrm{~L}^{-1} \mathrm{H}_{2} \mathrm{SO}_{4}$ solutions by cyclic voltammetry and chronoamperometry in a thermostated three-electrode cell. The electrochemical measurements were performed on a PC controlled VoltaLab Potentiostat PGZ 420 Electrochemical Interface. A Reversible Hydrogen Electrode (RHE) and vitreous carbon were used as reference and counter electrode, respectively. The active surface area of the electrodes was estimated from the integration of the hydrogen adsorption/desorption region of a cyclic voltammogram recorded at $50 \mathrm{mV} \mathrm{s}^{-1}$ in supporting electrolyte.

Spectroelectrochemical investigations was carried out in a Fourier transform IR spectrometer Bruker IFS 66v, with the sample compartment modified to allow the beam to be reflected on the electrode surface with an incidence angle of $65^{\circ}$, after passing through the IR window $\left(\mathrm{CaF}_{2}\right)$ of a conventional thin layer spectroelectrochemical cell. The beam path was under vacuum and a liquid $\mathrm{N}_{2}$ cooled $\mathrm{HgCdTe}$ detector (Infrared Associates) was used.

Using the Single Potential Alteration Infrared Reflectance Spectroscopy (SPAIRS) technique, ${ }^{15,17,19}$ reflectivities were recorded at $50 \mathrm{mV}$ intervals during the first voltammetric scan at a sweep rate of $1 \mathrm{mV} \mathrm{s}^{-1}$. Each spectrum resulted from the co-addition of 128 interferograms. Data acquisition required $20 \mathrm{~s}$, over $20 \mathrm{mV}$. Spectra were calculated as $-\Delta \mathrm{A}=\Delta \mathrm{R} / \mathrm{R}=\left(\mathrm{R}_{\mathrm{E}}-\mathrm{R}_{\mathrm{ERef}}\right) / \mathrm{R}_{\mathrm{ERef}}$ where the "reference" spectrum, $\mathrm{R}_{\mathrm{ERef}}$, was that recorded at the initial potential of $50 \mathrm{mV}$ vs. RHE. Similarly, using the Subtractively Normalized Interfacial Fourier Transform Infrared Reflectance Spectroscopy (SNIFTIRS) method, ${ }^{19,20,22,25}$ reflectivities were obtained at two electrode potentials $\mathrm{E}_{1}$ and $\mathrm{E}_{2}$ (the frequency of potential modulation was $25 \mathrm{mHz}$ and 128 interferograms were collected before the Fourier transform) and co-added 30 times at each potential. Final spectra were normalized as $-\Delta A=\Delta R / R=\left(R_{E 2}-R_{E 1}\right) / R_{E 1}$. For the SNIFTIRS and SPAIRS calculations, if $\mathrm{E}_{2}>\mathrm{E}_{1}$ or $\mathrm{E}>\mathrm{E}_{\mathrm{Ref}}$ so that, a positive absorption band indicates the consumption of species and a negative absorption band means the production of species. Both techniques allowed the detection of adsorbed species and reaction products at the electrode surface.

\section{Results and Discussion}

\section{Physicochemical characterization of the catalysts}

The scanning electron micrographs in Figure 1(A) show that the Pt-Sn alloy does not exhibit phase segregation. However, pores of $c a .35 \mu \mathrm{m}$ (black spots) due to gas bubbles formed during the melting process are clearly 
observed. On the other hand, the alloy Pt-Sn-W presents two distinct segregated regions (Figure 1(B)). The basic atomic compositions of Pt-Sn and Pt-Sn-W were evaluated by energy-dispersive $\mathrm{X}$-ray microanalyses and the results are summarized in Table 1 . The average atomic composition of both alloys is close to the expected values. EDX microanalyses performed on several areas of polished samples showed that Pt-Sn has a homogeneous composition while the Pt-Sn-W exhibits in region (1) of Figure 1(B) a composition of Pt-Sn (66:34) while the composition of region (2) of Figure 1(B) is Pt-Sn-W (40-20-40). The segregated region rich in $\mathrm{W}$ corresponds to $10 \%$ of the sample surface with many pores of distinct sizes.

Table 1. EDX results of the bulk composition of Pt-Sn and Pt-Sn-W alloys

\begin{tabular}{lll}
\hline Catalysts & \multicolumn{2}{c}{ Atomic composition } \\
& Nominal $(\%)$ & Experimental $(\%)$ \\
\hline Pt-Sn & $80: 20$ & $79: 21$ \\
Pt-Sn-W & $65: 30: 5$ & $\mathrm{Pt}_{66} \mathrm{Sn}_{34} / \mathrm{Pt}_{40} \mathrm{Sn}_{20} \mathrm{~W}_{40}$ \\
\hline
\end{tabular}
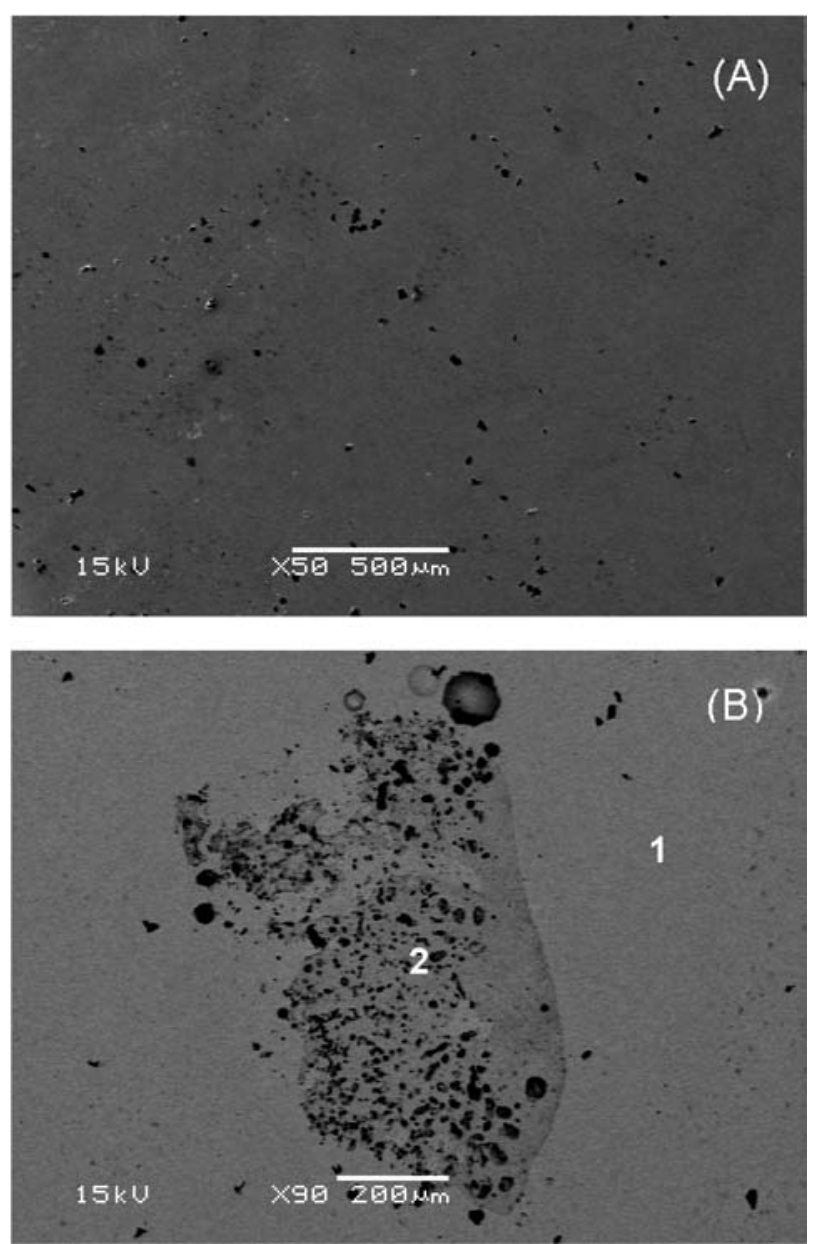

Figure 1. Scanning electron micrographs of (A) Pt-Sn and (B) Pt-Sn-W alloys.
XRD patterns for the binary Pt-Sn and ternary Pt-Sn-W catalysts are depicted in Figure 2. For comparison reason the XRD pattern for pure Pt was included in Figure 2. As can be seen, the main characteristic peaks of face-centred cubic (fcc) crystalline Pt (spatial group Fm-3m) appear in all XRD patterns with a shift to lower $2 \theta$ angle in reflections planes (111), (200), (220) and (311) for Pt-Sn and Pt-Sn-W alloys due to Sn presence in the Pt structure. Figure 2 shows also that the binary Pt-Sn alloy presents the characteristic peaks attributed to cubic $\mathrm{Pt}_{3} \mathrm{Sn}$ (spatial group $\mathrm{Pm}-3 \mathrm{~m})$ which is the predominant intermetallic phase. Additionally, a clear evidence for the formation of a Pt-Sn intermetallic phase is noticeable on Pt-Sn-W. Finally, the formation of $\mathrm{WO}_{3}$ on Pt-Sn-W is detected as small peaks at $25^{\circ}, 30^{\circ}$ and $33^{\circ}$.

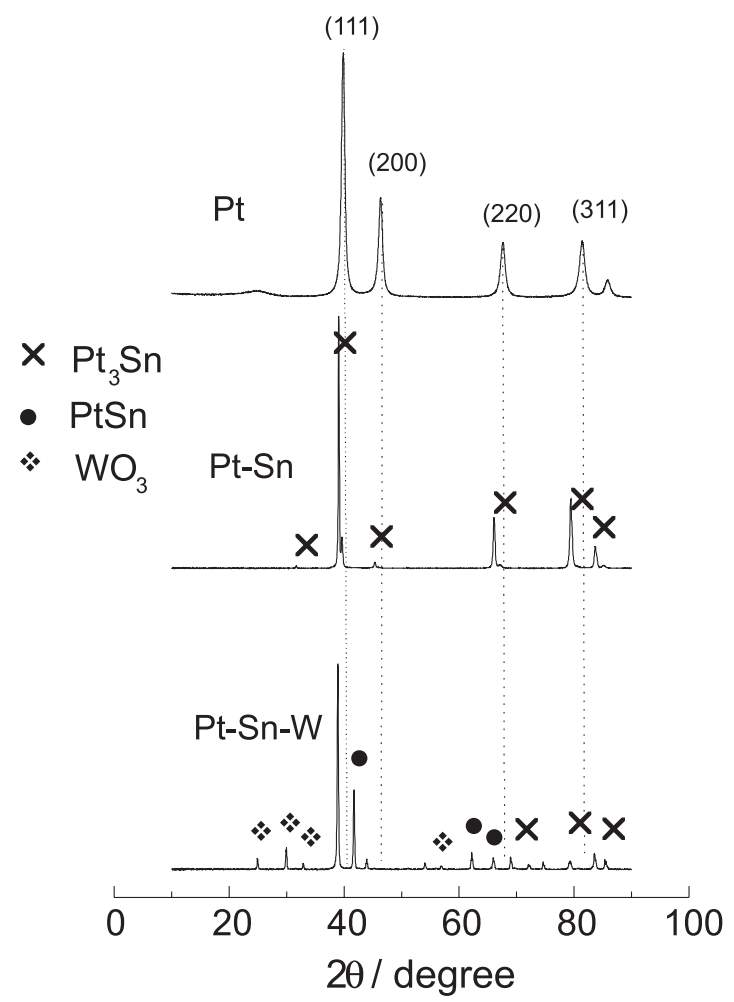

Figure 2. XRD diffractograms of Pt-Sn and Pt-Sn-W alloys.

\section{Electrochemical characterization of the catalysts}

Cyclic voltammogram profiles for Pt-Sn and Pt-Sn-W alloy electrodes in acid solution $\left(0.5 \mathrm{~mol} \mathrm{~L}^{-1} \mathrm{H}_{2} \mathrm{SO}_{4}\right)$ are presented in Figure 3. Voltammogram for $\mathrm{Pt}-\mathrm{Sn}$ electrode exhibits a very similar profile of the Pt electrode. The adsorption-desorption hydrogen regions are only due to the contribution of the Pt metal in the catalyst. Cyclic voltammogram for Pt-Sn-W electrode shows a Pt distorted shape with roundish peaks. This is mainly due to the presence of tungsten oxide $\left(\mathrm{WO}_{3}\right)$ formed during the 
catalyst preparation process. The estimation of the $\mathrm{Pt}$ surface area of the electrodes was done using the charge of hydrogen desorption peak. This procedure allows the comparison of the current density on different electrodes compositions.

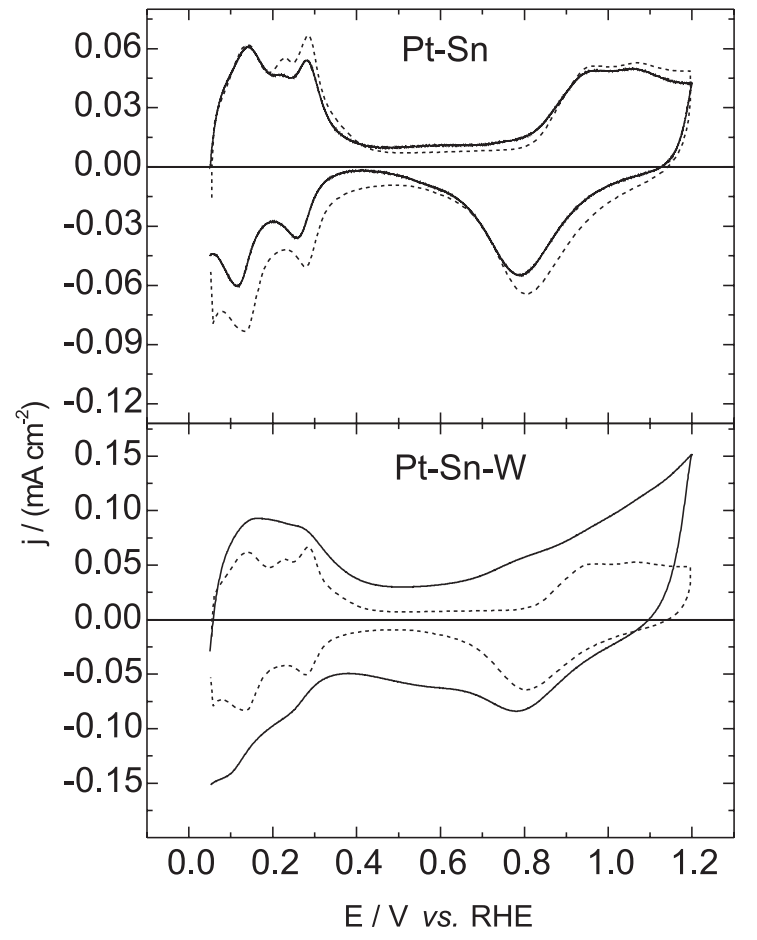

Figure 3. Voltammetric profiles of Pt-Sn and Pt-Sn-W catalysts in $0.5 \mathrm{~mol} \mathrm{~L}^{-1} \mathrm{H}_{2} \mathrm{SO}_{4}$ solution recorded at a scan rate of $50 \mathrm{mV} \mathrm{s}^{-1}$. Continuous line: alloy, dashed line: Pt.

\section{Electrochemical oxidation of ethanol}

Positive scan voltammetric curves in the presence of ethanol are showed in Figure 4. Ethanol electrooxidation starts at ca. $200 \mathrm{mV}$ earlier for Pt-Sn-W in comparison to a pure Pt electrode, as can be seen in Figure 4. Hydrogen adsorption/desorption peaks are clearly suppressed because the ethanol adsorption replaces the adsorbed hydrogen from the interface. On the other hand, the current for Pt-Sn is slightly smaller than the observed current for pure Pt. As pointed out by several papers in the literature, the presence of $\mathrm{Sn}$ in the catalyst can promote ethanol oxidation by either an electronic effect in the Pt-based electrode material or by activation of the interfacial water molecule necessary to complete the oxidation of adsorbed reaction intermediates leading to carbon dioxide, in the situation that the $\mathrm{C}-\mathrm{C}$ bond was broken, or the formation of acetic acid. ${ }^{9,40}$ Specially, at low potentials, from 250 to $450 \mathrm{mV} v$ s. RHE, the presence of $\mathrm{Sn}$ and $\mathrm{W}$ leads to an increase in the catalyst activity by reaching higher current densities, as shown in Figure 4.
In fact the introduction of $\mathrm{W}$ in the Pt-Sn leads to a significant increase in the electroactivity for the ternary alloy as compared to pure Pt. The synergistic effect obtained with the presence of Sn and W can be interpreted by the activation of interfacial water molecules at lower potentials than that observed for pure Pt. The bifunctional mechanism suggests, in this specific case, which oxygenated species on $\mathrm{Sn}$ assisted by $\mathrm{W}$, allows the removal of the reaction intermediates such as $\mathrm{CH}_{\mathrm{x}}$ and $\mathrm{CO}$ at lower potentials. ${ }^{41}$ Nevertheless, the current density for Pt-Sn electrode material is smaller than the observed for pure Pt indicating that Pt-Sn appears less active than Pt. These results are not in agreement with those from steady-state experiments (Figure 5) which showed the highest current densities for Pt-Sn compared to Pt at $400 \mathrm{mV}$ vs. RHE. This fact can be resulted from an unsuitable normalization or a surface poisoning due to the presence of Sn which is more noticeable in steady-state experiments.

However, the positive effect of the addition of $\mathrm{W}$ to Pt-Sn is obvious on the plot of the ratio of the current densities (see inset in Figure 4); This enhancement factor due to the presence of $\mathrm{W}$ goes through a maximum and it clearly appears that Pt-Sn-W is more active than Pt and $\mathrm{Pt}-\mathrm{Sn}$ in a potential range $(0.5-0.7 \mathrm{~V})$ where $\mathrm{Pt}$ is an efficient electrocatalyst.

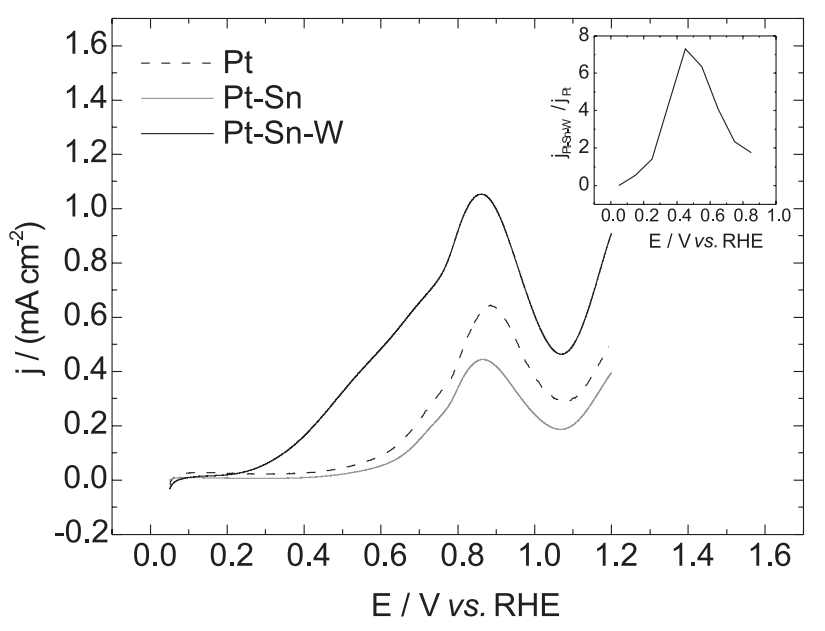

Figure 4. Anodic sweep curves of Pt, Pt-Sn and Pt-Sn-W catalysts in $0.5 \mathrm{~mol} \mathrm{~L}^{-1} \mathrm{H}_{2} \mathrm{SO}_{4}+0.2 \mathrm{~mol} \mathrm{~L}^{-1} \mathrm{C}_{2} \mathrm{H}_{5} \mathrm{OH}$ solution at a scan rate of $50 \mathrm{mV} \mathrm{s}^{-1}$. Inset: Plot of the ratio of current densities of Pt-Sn-W and Pt versus potential.

Chronoamperometry is a more adequate way to evaluate the electrocatalytic performance of the electrodes for ethanol oxidation at low potentials and under longterm operation condition. Thus, Figure 5 shows the chronoamperograms recorded for Pt, Pt-Sn and Pt-Sn-W at $400 \mathrm{mV} v s$. RHE. At this potential, the current densities 
reach a quasi-steady-state condition for all Pt-based studied electrodes. Additionally, Pt-Sn-W presents the highest current density and Pt-Sn shows much better performance than pure Pt. These results confirm that Pt-Sn-W is the best catalyst when compared to Pt-Sn and pure Pt.

For long-term operation, Pt-Sn and Pt-Sn-W electrodes show quite stable currents for ethanol oxidation after $25 \mathrm{~min}$ while the current for Pt-alone catalyst drops toward zero current at the beginning of the polarization. The origin of the immediate decay of the current for pure Pt can be associated to the significant accumulation of reaction intermediates that acts as surface poisoning species.

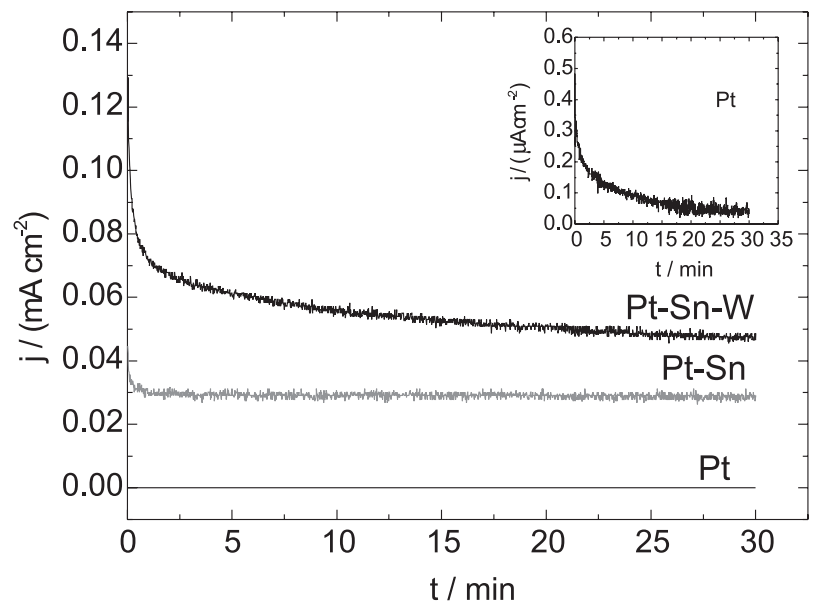

Figure 5. Potentiostatic oxidation of ethanol on Pt, Pt-Sn and Pt-Sn-W electrodes during 30 minutes at $400 \mathrm{mV}$ vs. RHE. Solution: $0.5 \mathrm{~mol} \mathrm{~L}^{-1}$ $\mathrm{H}_{2} \mathrm{SO}_{4}+0.2 \mathrm{~mol} \mathrm{~L}^{-1} \mathrm{C}_{2} \mathrm{H}_{5} \mathrm{OH}$. Inset: Chronoamperometric curve for $\mathrm{Pt}$ pure electrode.

\section{In situ spectroelectrochemical study of ethanol oxidation}

To obtain further information about reaction intermediates and reactions products formed during ethanol oxidation on Pt-Sn and Pt-Sn-W electrodes, in situ infrared reflectance spectroscopy was used employing SPAIRS and SNIFTIRS techniques in $0.5 \mathrm{~mol} \mathrm{~L}^{-1} \mathrm{H}_{2} \mathrm{SO}_{4}+0.2 \mathrm{~mol} \mathrm{~L}^{-1}$ $\mathrm{C}_{2} \mathrm{H}_{5} \mathrm{OH}$ solution.

Figure 6 shows the SPAIR spectra for Pt-Sn and Pt-Sn-W in the spectral range of wave numbers of 1,000-3,000 $\mathrm{cm}^{-1}$ and for potentials between 50 and $800 \mathrm{mV} v s$. RHE. These spectra were accumulated every $50 \mathrm{mV}$ during the first voltammetric cycle run at $1 \mathrm{mV} \mathrm{s}^{-1}$. The reference reflectivity used for the calculation of $\Delta \mathrm{R} / \mathrm{R}$ was taken at $50 \mathrm{mV} v s$. RHE. The main bands observed for both electrodes are attributed to the presence of interfacial water at $1,640 \mathrm{~cm}^{-1}$ and the band at $c a \cdot 1,725 \mathrm{~cm}^{-1}$ is ascribed to the stretching mode of the carbonyl group $(\mathrm{C}=\mathrm{O})$ indicative of acetic acid and/or acetaldehyde produced from the ethanol oxidation reaction. A band at $2,435 \mathrm{~cm}^{-1}$, attributed to $\mathrm{CO}_{2}$ formation is observed in potentials higher than $450 \mathrm{mV}$ vs. RHE for both Pt-based electrodes. At around 2,050 $\mathrm{cm}^{-1}$ it is possible to observe a small band due to the presence of adsorbed $\mathrm{CO}$ on the surface. The presence of this band is clearly observed by SNIFTIRS (see Figure 8). Finally, the band at $1,290 \mathrm{~cm}^{-1}$ is attributed to the vibration of acetic acid in the thin layer. Although the main desired reaction product formed in the complete oxidation of ethanol is the $\mathrm{CO}_{2}$, the most intense band observed in the SPAIR spectra of Figure 6 appears at $1,725 \mathrm{~cm}^{-1}$, that is attributed to the presence of acetic acid and/or acetaldehyde. The bands for $\mathrm{CO}_{2}$, acetaldehyde and/or acetic acid for Pt-Sn and Pt-Sn-W catalysts exhibit different intensities. In general, Pt-Sn displays the most intense relative bands for these species (see Figure 7(A) and (B)). These figures show the representative curves of the relative normalized intensities of IR bands for $\mathrm{CO}_{2}$ and acetaldehyde and/or acetic acid obtained from SPAIRS as a function of the electrode potential. It can be observed that the onset potential for both electrodes is about the same for $\mathrm{CO}_{2}$, acetaldehyde and/or acetic acid formation. The $\mathrm{CO}_{2}$ formation reaches a maximum value at ca. $750 \mathrm{mV} v s$. RHE, (see Figure 7(B)) and diminishes slightly up to $1,000 \mathrm{mV} v s$. RHE. At low potentials, the presence of $\mathrm{W}$ increases the formation of products $\left(\mathrm{CO}_{2}, \mathrm{CH}_{3} \mathrm{COOH} / \mathrm{CH}_{3} \mathrm{CHO}\right)$ compared to Pt-Sn. The amount of acetaldehyde and/or acetic acid formed keep growing with the increase of the potential (Figure 7(A)). This is mainly due to the accumulation of these species in the thin layer between the electrode surface and the $\mathrm{CaF}_{2}$ window.

The presence of many different bands in the spectra is clear evidence that during the ethanol oxidation, several different reaction steps are involved, as reported elsewhere. . $^{24,42}$

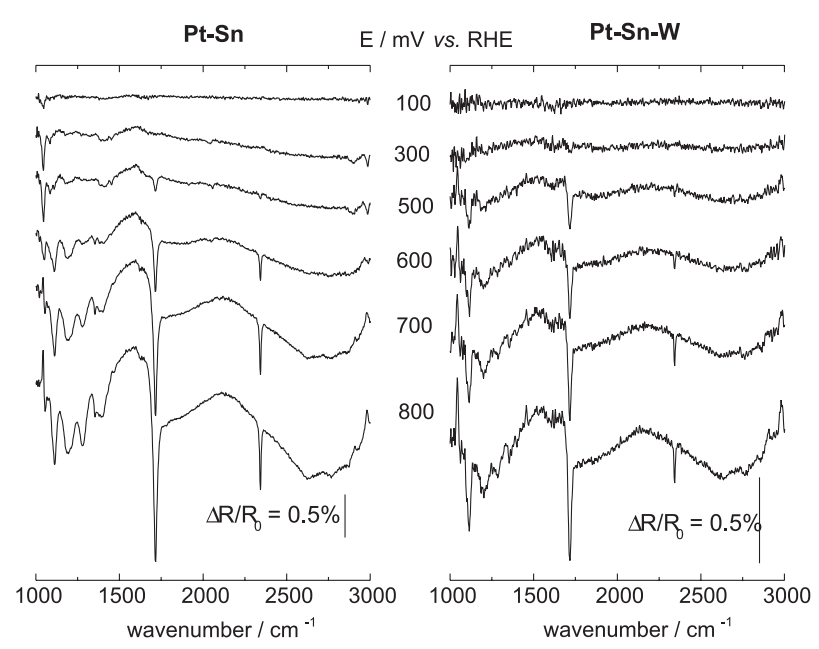

Figure 6. SPAIR spectra of the species resulting from the oxidation of ethanol in $0.5 \mathrm{~mol} \mathrm{~L}^{-1} \mathrm{H}_{2} \mathrm{SO}_{4}+0.2 \mathrm{~mol} \mathrm{~L}^{-1} \mathrm{C}_{2} \mathrm{H}_{5} \mathrm{OH}$ solution on Pt-Sn and $\mathrm{Pt}-\mathrm{Sn}-\mathrm{W}$ at potentials varying from 100 to $800 \mathrm{mV}$ vs. RHE. Reference spectrum taken at $50 \mathrm{mV}$ vs. RHE. 

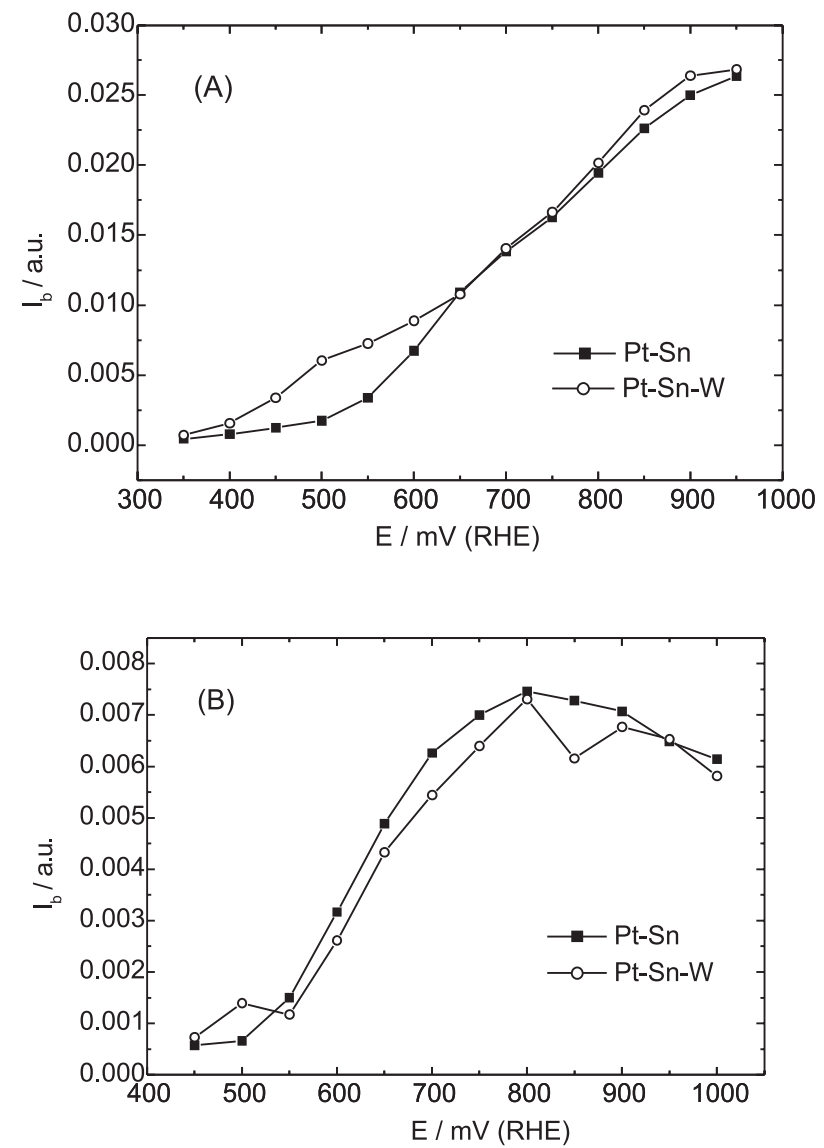

Figure 7. Band intensities of carbonyl (A) and $\mathrm{CO}_{2}(\mathrm{~B})\left(\mathrm{I}_{\mathrm{b}} \mathrm{Pt}-\mathrm{Sn}=3 \times \mathrm{I}_{\mathrm{b}}\right.$ Pt-Sn-W). IR Band intensities obtained from SPAIR spectra of Figure 6.

The band at $2,050 \mathrm{~cm}^{-1}\left(\mathrm{CO}_{\mathrm{L}}\right)$ is hardly observed by SPAIRS technique conversely to the SNIFTIRS. Figure 8 shows the SNIFTIR spectra recorded in the potential range from 50 to $750 \mathrm{mV}$ at constant potential modulation of $200 \mathrm{mV}$. The $\mathrm{CO}_{\mathrm{L}}$ band appears as a bipolar band at ca. $2,050 \mathrm{~cm}^{-1}$. This band appears clearly at the first potential modulation, showing that the initial ethanol adsorption step is dissociative. The intensity of this band increases up to 200-400 $\mathrm{mV}$ modulation and decreases until the modulation of $400-600 \mathrm{mV}$. This last potential $(400 \mathrm{mV})$ is sufficiently high to start the $\mathrm{CO}_{2}$ formation. Pt-Sn-W presents a lowest oxidation potential to oxidize $\mathrm{CO}$ to $\mathrm{CO}_{2}$ when compared to $\mathrm{Pt}-\mathrm{Sn}$. This behavior corroborates with the easy removal of adsorbed CO by its oxidation on Pt-Sn-W. This last catalyst appears to be more efficient to activate the interfacial water at lower potentials than Pt-Sn and both W and Sn are more oxophylic than Pt. Conversely, a band which corresponds to the final reaction product, $\mathrm{CO}_{2}$, can be observed at $2,345 \mathrm{~cm}^{-1}$. Although it is less intense than that for carbon monoxide, $\mathrm{CO}_{2}$ appears at a potential of $450 \mathrm{mV} v s$. RHE on both electrodes. From this behavior it can be inferred that $\mathrm{CO}_{2}$ production is not only due to adsorbed $\mathrm{CO}$ oxidation, once the decrease in the $\mathrm{CO}_{\text {ads }}$ band is not proportional to the increase in the $\mathrm{CO}_{2}$ band, suggesting that the formation of carbon dioxide is also due to acetaldehyde oxidation. This behavior can be explained by the bifunctional mechanism that occurs on these electrode surfaces at potentials lower than those for Pt alone.

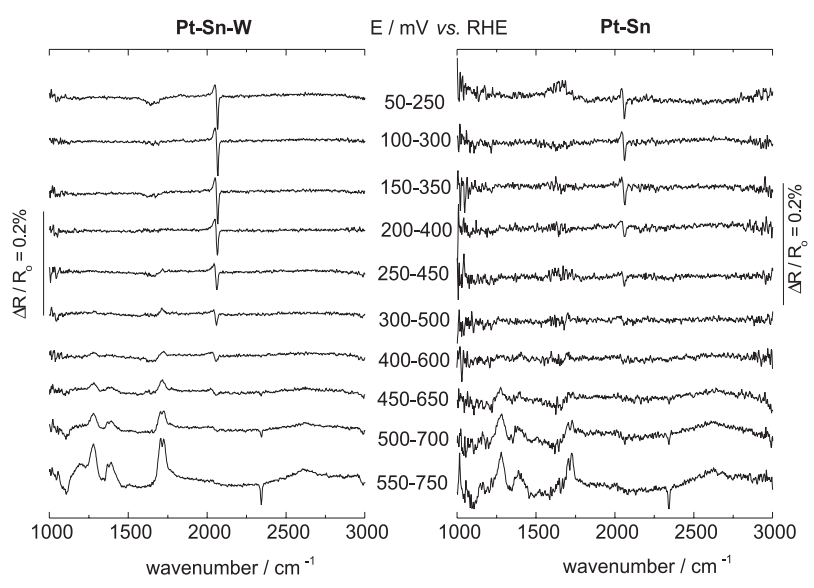

Figure 8. SNIFTIR spectra of the species formed during the ethanol oxidation in $0.5 \mathrm{~mol} \mathrm{~L}^{-1} \mathrm{H}_{2} \mathrm{SO}_{4}+0.2 \mathrm{~mol} \mathrm{~L}^{-1} \mathrm{C}_{2} \mathrm{H}_{5} \mathrm{OH}$ solution on Pt-Sn and Pt-Sn-W catalysts at various potential modulations from 50 to $750 \mathrm{mV} v s$. RHE.

As pointed out above, $\mathrm{CH}_{3} \mathrm{CHO}, \mathrm{CH}_{3} \mathrm{COOH}$ and $\mathrm{CO}_{2}$ were the different products detected by reflectance spectroscopy on Pt-Sn and Pt-Sn-W catalysts. Adsorbed $\mathrm{CO}$ was also detected spectroscopically. In agreement with these results a general parallel pathway mechanism for ethanol electrooxidation can be proposed as shown in Scheme 1. First of all, it can be assumed that ethanol adsorbs at the Pt surface followed by the $\alpha-\mathrm{C}-\mathrm{H}$ dissociation $\left(\mathrm{CH}_{3} \mathrm{CHOH}_{\text {ads }}\right)$. Part of this adsorbed ethanol can be dissociated by suffering the $\mathrm{C}-\mathrm{C}$ bond cleavage forming adsorbed linear $\mathrm{CO}$ and adsorbed $\mathrm{CH}_{\mathrm{x}}$. The other part of the adsorbed ethanol, can lead to the formation of adsorbed acetaldehyde. This path is apparently the simplest reaction step, which justifies the large amount of acetaldehyde found in band intensity of Figure 7(A). Part of the acetaldehyde can stay adsorbed in the electrode surface, part can desorbs in the solution and part can be oxidized to carbon dioxide. $\mathrm{CO}_{2}$ formation continues in potentials up to $1,000 \mathrm{mV} v s$. RHE, as suggested by Figure 7(B). This is an evidence that acetaldehyde can oxidize to $\mathrm{CO}_{2}$ at high potentials. The adsorbed acetaldehyde reacts with adsorbed oxygenated species to generate acetic acid as inferred in Figure 6. The adsorbed oxygenated species provide the $\mathrm{O}$ atom necessary to transform acetaldehyde in acid. This step occurs by a bifunctional mechanism and involves in total four-electron conversion pathway. Acetic acid formation is not useful for the overall process since it limits the total ethanol oxidation towards $\mathrm{CO}_{2}$. The adsorbed $\mathrm{CO}$ and adsorbed $\mathrm{CH}_{\mathrm{x}}$ species 


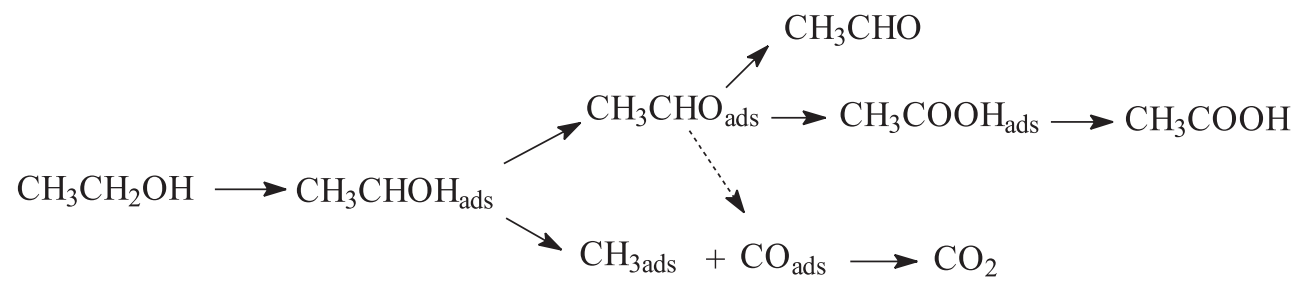

Scheme 1. Simplified parallel pathway mechanism for ethanol oxidation.

can react with adsorbed oxygenated species to form $\mathrm{CO}_{2}$. As can be seen in Figure 8, the adsorbed $\mathrm{CO}$ is no longer present in the catalyst surface at potentials higher than $450 \mathrm{mV}$. It is generally accepted that the $\mathrm{CO}$ oxidation on Pt bimetallic catalysts occurs by a bifunctional reaction mechanism ${ }^{43,44}$ and is described as a Langmuir-Hinshelwood type reaction. It can be considered in our case, that adsorbed oxygenated species is interfacial activated water on Sn and/ or $\mathrm{W}$ surface atoms and $\mathrm{CO}$ and $\mathrm{CH}_{\mathrm{x}}$ are adsorbed only on Pt. Experimental observations were supported by density functional theory (DFT) calculations which indicated that on bimetallic catalyst, $\mathrm{CO}$ is linked only to $\mathrm{Pt}$ atoms and not to the Sn atoms, whereas oxygenated species has an energetic preference for the Sn sites.

An ideal catalyst for ethanol oxidation would be the one that can result in the selective formation of $\mathrm{CH}_{3} \mathrm{CH}(\mathrm{OH})_{\text {ads }}$ species by the cleavage of $\mathrm{C}-\mathrm{H}$ bonds followed by the $\mathrm{C}-\mathrm{C}$ bond cleavage and subsequent oxidation of intermediates to $\mathrm{CO}_{2}$ in presence of adsorbed oxygenated species.

\section{Conclusions}

Pt-Sn and Pt-Sn-W catalysts studied here display electrocatalytic activity with respect to ethanol oxidation as evidenced by voltammetric and chronoamperometric measurements. Although ethanol oxidation involves theoretically 12 electrons per ethanol molecule when totally oxidized to $\mathrm{CO}_{2}$, the obtained results showed that its electrocatalytical oxidation on Pt-Sn and Pt-Sn-W catalysts led mainly to acetaldehyde and acetic acid. Adsorbed intermediates such as $\mathrm{CO}$ and reaction product as $\mathrm{CO}_{2}$ were also observed by in situ infrared reflectance spectroscopy. The presence of the last species suggests a cleavage of the $\mathrm{C}-\mathrm{C}$ bond, which occurred during ethanol oxidation on the Pt-Sn and Pt-Sn-W catalysts. Pt-Sn-W alloy is electrochemically more active than Pt-Sn for ethanol oxidation. A general simplified scheme for ethanol electrooxidation was proposed based in the experimental results found here, and it was possible to affirm that the presence of tin and tungsten is necessary to activate the catalysts when comparing to Pt alone.

\section{Acknowledgments}

This work was mainly conducted within the framework of a collaborative programme CAPES/COFECUB under grant No. 498/05. GTF also acknowledges FAPESP and CNPq, Brazil.

\section{References}

1. Cosmi, C.; Macchiato M.; Mangiamele L.; Marmo G.; Pietrapertos F.; Salvia M.; Energy Policy 2003, 31, 443.

2. Wachsmann, U.; Tolmasquim, M. T.; Renew Energy 2003, 28, 1029.

3. Muhida, R.; Park, M.; Dakkak, M.; Matsuura, K.; Tsuyosh, A.; Michira, M.; Sol. Energy Mater. Sol. Cells 2003, 75, 697.

4. Léger, J-M.; J. Appl. Electrochem. 2001, 31, 767.

5. Vigier, F.; Coutanceau, C.; Hahn, F.; Belgsir, E.M.; Lamy, C.; J. Electroanal. Chem. 2004, 563, 81.

6. Caillard, A.; Coutanceau, C.; Brault, P.; Mathias, J.; Léger, J-M.; J. Power Sources 2006, 162, 66.

7. Lamy, C.; Belgsir, E.M.; Léger, J-M.; J. Appl. Electrochem. 2001, 31, 799.

8. Maillard, F.; Gloaguen, F.; Hahn, F.; Léger, J-M.; Fuel Cells 2002, 2, 143.

9. Rousseau, S.; Coutanceau, C.; Lamy, C.; Léger, J-M.; J. Power Sources 2006, 158, 18.

10. Willsau, J.; Heitbaum, J.; J. Electroanal. Chem. 1985, 27, 194.

11. Bittins-Cattaneo, B.; Wilhelm, S.; Cattano, E.; Buschmann, H.W.; Vielstich, W.; Ber. Bunsenges. Phys. Chem. 1988, 92, 1210.

12. Iwasita, T.; Pastor, E.; Electrochim. Acta 1994, 39, 531.

13. Schmiemann, U.; Muller, U.; Baltruschat, H.; Electrochim. Acta 1995, 40, 99.

14. Beden, B.; Lamy, C.; Bewick, A.; Kumimatsu, K.; J. Electroanal. Chem. 1981, 121, 343.

15. Leung, L-W.H.; Weaver, M.J.; J. Electroanal. Chem. 1988, 240, 341.

16. Beden, B.; Lamy, C. In Spectroelectrochemistry, Theory and Practice; Gale, R. J., ed.; Plenum Press: New York, 1988, ch. 5.

17. Leung, L-W. H.; Chang, S-C.; Weaver, M. J.; J. Electroanal. Chem. 1989, 266, 317. 
18. Beden, B.; Léger, J-M.; Lamy, C. In Electrocatalytical Oxidation of Oxygenated Aliphatic Organic Compounds at Noble Metal Electrodes; Bockris, J. O. M.; Conway, B. E.; White, R. E., eds.; Modern Aspects of Electrochemistry, Plenum Press: New York, 1992, vol. 22, p. 97.

19. Iwasita, T.; Nart, F. C.; Gerischer H.; Tobias C.W., eds.; Advances in Electrochemical Science and Engineering, WileyVCH: New York, 1997, vol. 4, p. 123.

20. Kabbabi, A.; Faure, R.; Durand, R.; Beden, B.; Hahn, F.; Léger, J-M.; Lamy, C.; J. Electroanal. Chem. 1998, 444, 41.

21. Sun, S. -G. In Electrocatalysis, Frontiers in Electrochemistry; Lipkowski, J.; Ross, Ph. N., eds., Wiley-VCH: New York, 1998, p. 243.

22. Iwasita, T.; Hoster, H.; John-Anaker, A.; Lin, W.F.; Vielstich, W.; Langmuir 2000, 16, 522.

23. Rodriguez, J. L.; Pastor, E.; Xia, X. H.; Iwasita, T.; Langmuir 2000, 16, 5479.

24. Iwasita, T.; Electrochim. Acta 2002, 47, 3663.

25. Camara, G. A.; Iwasita, T.; J. Electroanal. Chem. 2005, 578, 315.

26. Silva-Chong, J.; Méndez, E.; Rodriguez, J. L.; Arévalo, M. C.; Pastor, E.; Electrochim. Acta 2002, 47, 1441.

27. Roth, C.; Martz, N.; Hahn, F., Léger, J. -M.; Lamy, C.; Fuess, H.; J. Electrochem. Soc. 2002, 149, 433.

28. Shin, J.; Tornquist, W. J.; Korzeniewski, C.; Hoaglund, C. S.; Surf. Sci. 1996, 364, 122.

29. Watanabe, M.; Motoo, S.; J. Electroanal. Chem. 1975, 60, 275.

30. Crown, A.; Moraes, I. R.; Wieckowski, A.; J. Electroanal. Chem. 2001, 500, 333.

31. Waszczuk, P.; Lu, C. -Q.; Wieckowski, A.; Lu, C.; Rice, C.; Masel, R. I.; Electrochim. Acta 2002, 47, 3637.

32. Kokoh, K. B., Hahn, F.; Belgsir, E. M; Lamy, C.; de Andrade, A. R.; Olivi, P.; Motheo, A. J.; Tremiliosi-Filho, G.; Electrochim. Acta 2004, 49, 2077.

33. Tremiliosi-Filho, G.; Kim, H.; Chrzanowski, W.; Wieckowski, A.; Grzybowska, B.; Kulesza, P.; J. Electroanal. Chem. 2001, $467,143$.
34. Spendelow, J. S.; Lu, G. Q.; Kenis, P. J. A.; Wieckowski, A.; J. Electroanal. Chem. 2004, 568, 215.

35. Roth, C.; Papworth, A. J.; Hussain, I.; Nichols, R. J.; Schiffrin, D. J.; J. Electroanal. Chem. 2005, 581, 79.

36. Frelink, T.; Vissche, W.; Van Veen, J. A. R.; Langmuir 1996, $12,3702$.

37. Lu, C.; Rice, C.; Masel, M.; Babu, P. K.; Waszczuk, P.; Kim, H. S.; Oldfield, E.; Wieckowski, A.; J. Phys. Chem. B 2002, 106, 958.

38. Liu, R.; Iddir, H.; Fan, Q.; Hou, G.; Bo, A.; Ley, K. L.; Smotkin, E. S.; Sung, Y. -E.; Kim, H.; Thomas, S.; Wieckowski, A.; J. Phys. Chem. B 2000, 104, 3518.

39. Souza, J. P. I.; Rabelo, F. J. B.; de Moraes, I. R.; Nart, F. C.; J. Electroanal. Chem. 1997, 420, 17.

40. Simões, F. C.; dos Anjos, D. M.; Vigier, F.; Léger, J. -M.; Hahn, F.; Coutanceau, C.; Gonzalez, E. R.; Tremiliosi-Filho, G.; de Andrade, A. R.; Olivi, P.; Kokoh, K. B.; J. Power Sources 2007, $167,1$.

41. dos Anjos, D. M.; Hahn, F.; Léger, J. -M.; Kokoh, K. B.; Tremiliosi-Filho, G.; J. Solid State Electrochem. 2007, 11, 1567.

42. Léger, J. -M.; Rousseau, S.; Coutanceau, C.; Hahn, F.; Lamy, C.; Electrochim. Acta 2005, 50, 5118.

43. Shubina, T. E.; Koper, T. M.; Electrochim. Acta 2002, 30, 3621.

44. Léger, J. -M.; Hahn, F. In In Situ Spectroscopic Studies of Adsorption at the Electrode and Electrocatalysis; Sun, S. G.; Christensen, P. A.; Wieckowski, A., eds., Elsevier Science: Amsterdan, 2007, vol. 3.

Received: October 1, 2007

Web Release Date: May 8, 2008

FAPESP helped in meeting the publication costs of this article. 